\title{
Informasi Laba, Aliran Kas dan Harga Saham dalam Kaitannya dengan Siklus Hidup Perusahaan
}

\author{
Ni Wayan Ade Suyanti ${ }^{1}$ \\ Dodik Ariyanto ${ }^{2}$ \\ I Putu Sudana ${ }^{3}$ \\ Maria Mediatrix Ratna Sari ${ }^{4}$ \\ 1,2,3,4Fakultas Ekonomi dan Bisnis Universitas Udayana, Indonesia \\ ${ }^{*}$ Correspondences : suyantiade@gmail.com
}

\begin{abstract}
ABSTRAK
Penelitian ini bertujuan untuk menguji pengaruh informasi laba terhadap harga saham dalam kaitannya dengan siklus hidup perusahaan pada tahap growth, mature dan decline. Penelitian ini dilakukan di perusahaan sektor manufaktur yang terdaftar di Bursa Efek Indonesia (BEI) tahun 2015-2019 dengan menggunakan data sekunder yaitu laporan tahunan perusahaan. Metode penentuan sampel menggunakan metode purposive sampling. Teknik Analisis data yang digunakan adalah regresi linier berganda. Hasil analisis menunjukkan bahwa informasi laba perusahaan saat tahap growth dan mature berpengaruh positif pada harga saham sedangkan pada tahap decline berpengaruh negatif. Informasi arus kas aktivitas operasi perusahaan saat tahap growth, mature dan decline berpengaruh positif pada harga saham. Informasi arus kas aktivitas investasi perusahaan saat tahap growth dan mature berpengaruh negatif pada harga saham sedangkan pada tahap decline berpengaruh positif. Informasi arus kas aktivitas pendanaan perusahaan saat tahap growth, mature dan decline berpengaruh positif pada harga saham.
\end{abstract}

Kata Kunci: $\quad$ Informasi Laba; Aliran Kas; Harga Saham; Siklus Hidup Perusahaan.

\section{Earnings and Cash Flow Information on Stock Prices in Relation to The Company's Life Cycle}

\section{ABSTRACT}

This study aims to examine the effect of earnings information on stock prices in relation to the company's life cycle at the growth, mature and decline stages. This research was conducted in manufacturing sector companies listed on the Indonesia Stock Exchange (IDX) in 2015-2019 using secondary data, namely the company's annual report. The method of determining the sample using purposive sampling method. The data analysis technique used is multiple linear regression. The results of the analysis show that the company's profit information during the growth and mature stages has a positive effect on stock prices while at the decline stage it has a negative effect. Information on the cash flow of the company's operating activities during the growth, mature and decline stages has a positive effect on stock prices. Information on the cash flow of the company's investment activities during the growth and mature stages has a negative effect on stock prices while at the decline stage it has a positive effect. Information on the cash flow of the company's funding activities during the growth, mature and decline stages has a positive effect on stock prices.

Keywords: $\quad$ Profit Information; Cash Flow; Stock price; Company Life Cycle.

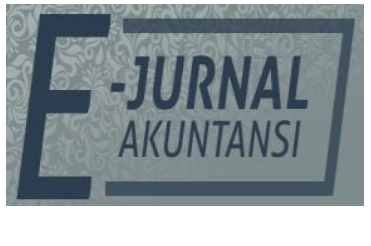

e-ISSN 2302-8556

Vol. 32 No. 1

Denpasar, Januari 2022

Hal. 43-61

DOI:

10.24843/EJA.2022.v32.i01.p04

PENGUTIPAN:

Suyanti, N. W. A., Ariyanto, D., Sudana, I. P. \& Sari, M. M. R. (2022). Informasi Laba, Aliran Kas dan Harga Saham dalam Kaitannya dengan Siklus Hidup Perusahaan. E-Jurnal Akuntansi, 32(1), 43-61

RIWAYAT ARTIKEL: Artikel Masuk: 11 Desember 2021 Artikel Diterima: 12 Januari 2022

Artikel dapat diakses : https://ojs.unud.ac.id/index.php/Akuntansi/index 


\section{PENDAHULUAN}

Teori sinyal membahas bagaimana sebaiknya dan seharusnya sinyal-sinyal keberhasilan atau kegagalan harus disampaikan. Teori ini menjelaskan mengapa perusahaan mempunyai inisiatif dan dorongan untuk memberikan informasi kepada pihak eksterneal (Wolk et al., 2001). Dorongan perusahaan untuk memberikan informasi tersebut disebabkan adanya asimetri infromasi antara manajemen dan pihak eksternal. Asimetri informasi terjadi apabila manajemen mengetahui lebih banyak informasi serta prospek perusahaan dimasa mendatang dibandingkan pihak eksternal (Wolk et al., 2001). Sinyal yang diberikan dapat dilakukan melalui pengungkapan (disclosure) informasi akuntansi. Laporan keuangan merupakan sarana pengkomonikasian informasi keuangan kepada pihak-pihak diluar perusahaan (Diesnawati, 2010).

Pasar modal adalah tempat dimana berbagai pihak khususnya perusahaan menjual saham dan obligasi dengan tujuan dari hasil penjualan tersebut nantinya akan dipergunakan sebagai tambahan dana untuk memperkuat dana perusahaan (Amir \& Suaryana, 2019). Menurut Darmadji \& Hendy (2011), saham (stock) dapat didefinisikan sebagai tanda penyertaan atau pemilikan seseorang atau badan dalam suatu perusahaan atau perseroan terbatas. Dalam berinvestasi di pasar modal semakin tinggi return yang diharapkan, semakin tinggi pula risiko yang akan ditanggung sehingga para investor harus berhati-hati dalam melakukan investasi. Menurut Ang (2007) menyatakan bahwa pendapatan yang diinginkan oleh para pemegang saham adalah pendapatan dividen (dividend yield) dan capital gain. Dividend yield digunakan untuk mengukur jumlah dividen per lembar saham terhadap harga saham dalam bentuk persentase. Semakin besar dividend yield, maka investor akan semakin tertarik untuk membeli saham tersebut.

Dalam berinvestasi di pasar modal semakin tinggi return yang diharapkan, semakin tinggi pula risiko yang akan ditanggung sehingga para investor harus berhati-hati dalam melakukan investasi dan semakin tinggi harga pasar menunjukkan bahwa saham tersebut juga semakin diminati oleh investor karena semakin tinggi harga saham akan menghasilkan capital gain yang semakin besar pula (Simanjuntak, 2021). Laporan keuangan merupakan salah satu jenis informasi yang mudah didapatkan dibandingkan informasi lainnya, dan dengan menggunakan laporan keuangan investor juga akan dapat menghitung berapa besarnya pertumbuhan laba yang telah dicapai oleh perusahaan terhadap jumlah saham perusahaan (Harahap, 2017).

Menurut Sukardi \& Kurniawan (2010) laporan arus kas adalah laporan keuangan yang memperlihatkan penerimaan kas dan pengeluaran kas selama periode waktu tertentu yang berasal dari aktivitas operasi, investasi dan pendanaan. Informasi tentang arus kas suatu perusahaan berguna bagi para pemakai laporan keuangan sebagai dasar untuk menilai kemampuan perusahaan dalam menghasilkan kas dan setara kas serta menilai kebutuhan perusahaan untuk menggunakan arus kas tersebut.

Dalam perspektif manajemen keuangan, tujuan perusahaan adalah memaksimumkan nilai perusahaan, yang juga berarti memaksimumkan kekayaan pemegang saham (Kurnia, 2019). Pada sebuah perusahaan yang sudah go public, nilai sebuah perusahaan tercermin pada harga sahamnya yang diperdagangkan di bursa efek. Jika harga saham sebuah perusahaan turun maka nilai perusahaan 
tersebut turun, kekayaan pemegang sahamnya juga turun. Tujuan memaksimalisasi nilai perusahaan ini harus melandasi semua keputusan yang diambil dalam perusahaan (Ismaya, 2010). Bowen et al. (1986) menyatakan bahwa manfaat laporan arus kas adalah untuk memprediksi kegagalan, menaksir risiko, memperediksi pemberian pinjaman, penilaian perusahaan, dan memberikan informasi tambahan pada pasar modal. Lee \& Choi (2002) menyatakan bahwa informasi yang disajikan arus kas lebih bermanfaat dalam menilai atau menganalisis keputusan, baik tentang investasi saham maupun tujuan peramalan arus kas lainya.

Penelitian ini bertujuan untuk menguji pengaruh informasi laba dan informasi arus kas operasi, investasi serta pendanaan terhadap harga saham dalam kaitannya dengan siklus hidup perusahaan pada tahap growth, mature dan decline, dengan menguji pengaruh antar variabel tersebut akan memudahkan investor dalam melakukan analisis saham berdasarkan harga saham yang dikaitkan dengan siklus hidup perusahaan. Pemilihan perusahaan manufaktur sebagai objek penelitian karena jumlah perusahaan yang masuk kategori perusahaan manufaktur lebih banyak dibandingkan dengan perusahaan lainnya. Berdasarkan latar belakang yang telah dijelaskan sebelumnya, kemudian disusun konsep yang menjelaskan hubungan informasi laba dan aliran kas masih dianggap sebagai salah satu sumber informasi penting oleh para investor dan kreditur di dalam menilai kinerja suatu perusahaan. Dimana informasi laba dan aliran kas yang terdiri dari aliran kas dari aktivitas operasi, aliran kas dari aktivitas investasi dan aliran kas dari aktivitas pendanaan tersebut memiliki pengaruh pada harga saham dalam kaitannya dengan siklus hidup perusahaan. Penelitian ini nantinya akan berkontribusi secara teoritis dan praktis, secara teoritis dapat memberikan kajian literatur untuk melakukan penelitian dimasa mendatang dan secara praktis dapat membantu para investor dalam melakukan pertimbangan dalam melakukan analisis terhadap harga saham yang ada di bursa efek. Konsep penelitian dapat disajikan Gambar 1.

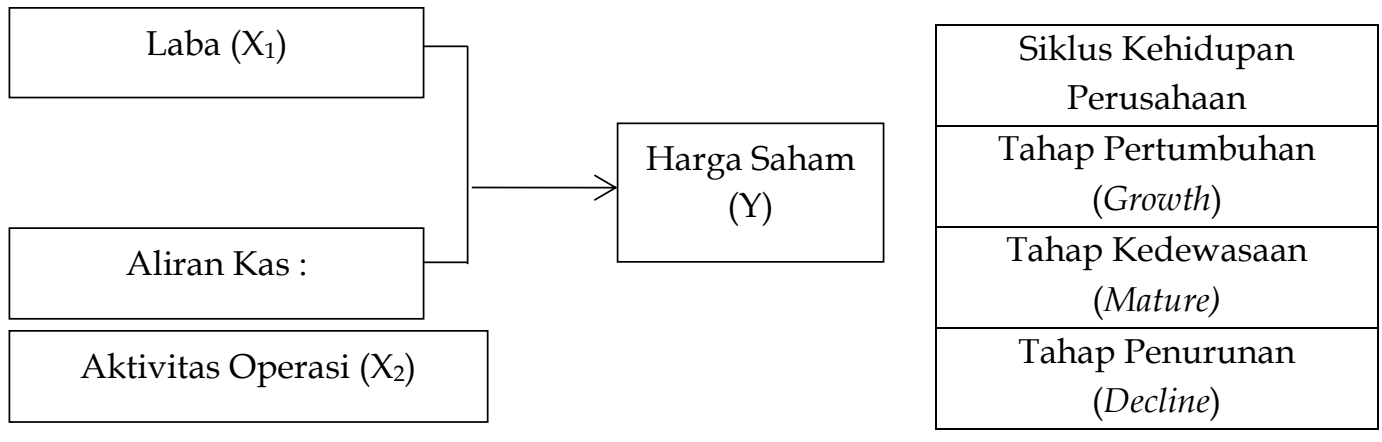

Aktivitas Investasi $\left(X_{3}\right)$

Aktivitas Pendanaan $\left(\mathrm{X}_{4}\right)$

Sumber: Data Penelitian, 2021

Gambar 1. Konsep Penelitian 
Berdasarkan penelitian Atmini (2002) yang menemukan bahwa pada tahap growth besarnnya laba berpengaruh signifikan dan berhubungan positif dengan nilai pasar ekuitas. Diesnawati (2010) menyatakan pada tahap decline informasi laba berpengaruh negatif terhadap harga saham, Yendrawati \& Pratiwi (2015) menyatakan baik pada tahap growth laba lebih memiliki relevansi nilai daripada arus kas terhadap harga saham. Diversifikasi geografis tidak secara signifikan memoderasi hubungan antara siklus hidup perusahaan di fase pertumbuhan dan cash holding. Diversifikasi geografis secara signifikan memoderasi hubungan antara CSR dan cash holding. Setiawan \& Nofrisel (2019) hubungan antara persediaan dan kinerja keuangan adalah positif pada tahap pertumbuhan awal dari siklus hidup organisasi dan berubah menjadi negatif pada tahap pertumbuhan akhir. Dari uraian tersebut, maka dihipotesiskan sebagai berikut.

$\mathrm{H}_{1}$ : Informasi laba perusahaan saat tahap growth berpengaruh positif pada harga saham.

Black (1998) yang menyatakan bahwa pada tahap mature laba berhubungan positif dengan nilai pasar ekuitas. Yendrawati \& Pratiwi (2015) menyatakan baik pada tahap mature laba lebih memiliki relevansi nilai daripada arus kas terhadap harga saham, sedangkan Husna \& Haryanto (2019) siklus hidup perusahaan di fase kedewasaan tidak berpengaruh terhadap cash holding, siklus hidup perusahaan di fase penurunan tidak berpengaruh terhadap cash holding, sedangkan Husna \& Haryanto (2019) siklus hidup perusahaan di fase kedewasaan tidak berpengaruh terhadap cash holding, siklus hidup perusahaan di fase penurunan tidak berpengaruh terhadap cash holding. Dari uraian tersebut, maka dihipotesiskan sebagai berikut.

$\mathrm{H}_{2}$ : Informasi laba perusahaan saat tahap mature berpengaruh positif pada harga saham.

Tahap terakhir dari siklus hidup perusahaan yaitu tahap decline, posisi kompetitif perusahaan sudah tidak menarik lagi, persaingan semakin tajam dan pangsa pasar potensialnya semakin sempit. Kondisi ini mempersulit kemampuan perusahaan dalam menghasilkan laba dan biasanya perusahaan melaporkan laba negatif. Walaupun laba bernilai negatif, perusahaan memiliki kesempatan tumbuh yang besar dan prospek untuk menghasilkan laba positif di masa depan dengan harapan perusahaan melakukan investasi pada lini produk baru sehingga diharapkan harga saham tinggi. Laba diharapkan berhubungan negatif dengan harga saham. Diesnawati (2010) menyatakan pada tahap decline informasi laba berpengaruh negatif terhadap harga saham. Dari uraian tersebut, maka dihipotesiskan sebagai berikut.

$\mathrm{H}_{3}$ : Informasi laba perusahaan saat tahap decline berpengaruh negatif pada harga saham.

Pengaruh arus kas dari aktivitas operasi (AKO) terhadap harga saham dalam kaitannya dengan siklus hidup perusahaan didasarkan pada teori sinyal, karena teori sinyal membahas bagaimana sebaiknya dan seharusnya sinyal-sinyal keberhasilan atau kegagalan harus disampaikan (Ross, 1977). Teori ini menjelaskan mengapa perusahaan mempunyai inisiatif dan dorongan untuk memberikan informasi kepada pihak eksternal (Setiawanta \& Hakim, 2019). Salah satu informasi yang dapat melengkapi gambaran kondisi ekonomi peusahaan adalah informasi mengenai siklus hidup perusahaan. Secara umum siklus hidup 
perusahaan dibedakan menjadi empat tahap yaitu start-up, growth, mature dan decline. Berdasarkan penelitian sebelumnya Yendrawati \& Pratiwi (2015) menyatakan baik pada tahap growth laba lebih memiliki relevansi nilai daripada arus kas terhadap harga saham. Black (1998) yang berhasil menemukan bukti bahwa aliran kas operasi pada tahap growth berhubungan positif dengan nilai pasar ekuitas. Diesnawati (2010) yang memperoleh bukti bahwa aliran kas operasi pada tahap mature aliran kas operasi berhubungan positif pada harga saham, dan Black (1998) menunjukkan bahwa aliran kas operasi pada tahap decline berhubungan positif dengan nilai pasar ekuitas. Dari uraian tersebut, maka dihipotesiskan sebagai berikut.

$\mathrm{H}_{4}$ : Informasi AKO perusahaan saat tahap growth berpengaruh positif pada harga saham.

Berdasarkan penelitian sebelumnya Yendrawati \& Pratiwi (2015) menyatakan baik pada tahap mature laba lebih memiliki relevansi nilai daripada arus kas terhadap harga saham. Diesnawati (2010) yang memperoleh bukti bahwa aliran kas operasi pada tahap mature aliran kas operasi berhubungan positif pada harga saham. Dari uraian tersebut, maka dihipotesiskan sebagai berikut.

$\mathrm{H}_{5}$ : Informasi AKO perusahaan saat tahap mature berpengaruh positif pada harga saham.

Pengaruh arus kas dari aktivitas operasi (AKO) terhadap harga saham dalam kaitannya dengan siklus hidup perusahaan didasarkan pada teori sinyal, salah satu informasi yang dapat melengkapi gambaran kondisi ekonomi peusahaan adalah informasi mengenai siklus hidup perusahaan. Black (1998) menunjukkan bahwa aliran kas operasi pada tahap decline berhubungan positif dengan nilai pasar ekuitas.Dari uraian tersebut, maka dihipotesiskan sebagai berikut.

$\mathrm{H}_{6}$ : Informasi AKO perusahaan saat tahap decline berpengaruh positif pada harga saham.

Pengaruh arus kas dari aktivitas investasi (AKI) terhadap harga saham dalam kaitannya dengan siklus hidup perusahaan didasarkan pada teori sinyal, karena teori sinyal membahas bagaimana sebaiknya dan seharusnya sinyal-sinyal keberhasilan atau kegagalan harus disampaikan (Widiyanti, 2019). Teori ini menjelaskan mengapa perusahaan mempunyai inisiatif dan dorongan untuk memberikan informasi kepada pihak eksternal. Salah satu informasi yang dapat melengkapi gambaran kondisi ekonomi peusahaan adalah informasi mengenai siklus hidup perusahaan. Secara umum siklus hidup perusahaan dibedakan menjadi empat tahap yaitu start-up, growth, mature dan decline. Berdasarkan penelitian sebelumnya Yendrawati \& Pratiwi (2015) menyatakan baik pada tahap growth laba lebih memiliki relevansi nilai daripada arus kas terhadap harga saham, sedangkan Husna \& Haryanto (2019) menyatakan siklus hidup perusahaan di fase pengenalan berpengaruh negatif terhadap cash holding, siklus hidup perusahaan di fase pertumbuhan tidak berpengaruh terhadap cash holding, siklus hidup perusahaan di fase kedewasaan tidak berpengaruh terhadap cash holding, siklus hidup perusahaan di fase penurunan tidak berpengaruh terhadap cash holding. Diversifikasi geografis tidak secara signifikan memoderasi hubungan antara siklus hidup perusahaan di fase pertumbuhan dan cash holding. Diversifikasi geografis secara signifikan memoderasi hubungan antara CSR dan cash holding. Atmini 
(2002) dan Black (1998) yang menemukan bahwa pada tahap growth aliran kas investasi berpengaruh dan berhubungan negatif dengan harga saham, dan Diesnawati (2010) menyatakan aliran kas investasi pada tahap decline berpengaruh positif terhadap harga saham. Setiawan \& Nofrisel (2019) hubungan antara persediaan dan kinerja keuangan adalah positif pada tahap pertumbuhan awal dari siklus hidup organisasi dan berubah menjadi negatif pada tahap pertumbuhan akhir. Dari uraian tersebut, maka dihipotesiskan sebagai berikut.

$\mathrm{H}_{7}$ : Informasi AKI perusahaan saat tahap growth berpengaruh negatif pada harga saham.

Pengaruh arus kas dari aktivitas investasi (AKI) terhadap harga saham dalam kaitannya dengan siklus hidup perusahaan didasarkan pada teori sinyal, karena teori sinyal membahas bagaimana sebaiknya dan seharusnya sinyal-sinyal keberhasilan atau kegagalan harus disampaikan (Widiyanti, 2019). dan Black (1998) yang menemukan bahwa pada tahap mature aliran kas investasi berpengaruh dan berhubungan negatif dengan harga saham, dan Yendrawati \& Pratiwi (2015) menyatakan baik pada tahap mature laba lebih memiliki relevansi nilai daripada arus kas terhadap harga saham. Dari uraian tersebut, maka dihipotesiskan sebagai berikut.

$\mathrm{H}_{8}$ : Informasi AKI perusahaan saat tahap mature berpengaruh negatif pada harga saham.

Pengaruh arus kas dari aktivitas investasi (AKI) terhadap harga saham dalam kaitannya dengan siklus hidup perusahaan didasarkan pada teori sinyal, karena teori sinyal membahas bagaimana sebaiknya dan seharusnya sinyal-sinyal keberhasilan atau kegagalan harus disampaikan (Widiyanti, 2019). Diesnawati (2010) menyatakan aliran kas investasi pada tahap decline berpengaruh positif terhadap harga saham. Setiawan \& Nofrisel (2019) hubungan antara persediaan dan kinerja keuangan adalah positif pada tahap pertumbuhan awal dari siklus hidup organisasi dan berubah menjadi negatif pada tahap pertumbuhan akhir.

$\mathrm{H}_{9}$ : Informasi AKI perusahaan saat tahap decline berpengaruh positif pada harga saham.

Pengaruh arus kas dari aktivitas pendanaan (AKP) terhadap harga saham dalam kaitannya dengan siklus hidup perusahaan didasarkan pada teori sinyal, karena teori sinyal membahas bagaimana sebaiknya dan seharusnya sinyal-sinyal keberhasilan atau kegagalan harus disampaikan. Teori ini menjelaskan mengapa perusahaan mempunyai inisiatif dan dorongan untuk memberikan informasi kepada pihak eksterneal. Salah satu informasi yang dapat melengkapi gambaran kondisi ekonomi peusahaan adalah informasi mengenai siklus hidup perusahaan. Secara umum siklus hidup perusahaan dibedakan menjadi empat tahap yaitu start-up, growth, mature dan decline (Tosungku, 2021). Berdasarkan penelitian sebelumnya Yendrawati \& Pratiwi (2015) menyatakan baik pada tahap growth maupun mature laba lebih memiliki relevansi nilai daripada arus kas terhadap harga saham, sedangkan Husna \& Haryanto (2019) menyatakan siklus hidup perusahaan di fase pengenalan berpengaruh negatif terhadap cash holding, siklus hidup perusahaan di fase pertumbuhan tidak berpengaruh terhadap cash holding, siklus hidup perusahaan di fase kedewasaan tidak berpengaruh terhadap cash holding, siklus hidup perusahaan di fase penurunan tidak berpengaruh terhadap cash holding. Diversifikasi geografis tidak secara signifikan memoderasi 
hubungan antara siklus hidup perusahaan di fase pertumbuhan dan cash holding. Diversifikasi geografis secara signifikan memoderasi hubungan antara CSR dan cash holding. Black (1998) dan kemudian Atmini (2002) yang menemukan bahwa aliran kas pendanaan pada tahap growth dan mature berhubungan positif dengan harga saham, dan Diesnawati (2010) menyatakan aliran kas pendanaan pada tahap decline berpengaruh positif terhadap harga saham. Setiawan \& Nofrisel (2019) hubungan antara persediaan dan kinerja keuangan adalah positif pada tahap pertumbuhan awal dari siklus hidup organisasi dan berubah menjadi negatif pada tahap pertumbuhan akhir. Dari uraian tersebut, maka dihipotesiskan sebagai berikut.

$\mathrm{H}_{10}$ : Informasi AKP perusahaan saat tahap growth berpengaruh positif pada harga saham.

Pengaruh arus kas dari aktivitas pendanaan (AKP) terhadap harga saham dalam kaitannya dengan siklus hidup perusahaan didasarkan pada teori sinyal, karena teori sinyal membahas bagaimana sebaiknya dan seharusnya sinyal-sinyal keberhasilan atau kegagalan harus disampaikan. Black (1998) dan kemudian Atmini (2002) yang menemukan bahwa aliran kas pendanaan pada tahap mature berhubungan positif dengan harga saham. Setiawan \& Nofrisel (2019) hubungan antara persediaan dan kinerja keuangan adalah positif pada tahap pertumbuhan awal dari siklus hidup organisasi dan berubah menjadi negatif pada tahap pertumbuhan akhir. Dari uraian tersebut, maka dihipotesiskan sebagai berikut.

$\mathrm{H}_{11}$ : Informasi AKP perusahaan saat tahap mature berpengaruh positif pada harga saham.

Pengaruh arus kas dari aktivitas pendanaan (AKP) terhadap harga saham dalam kaitannya dengan siklus hidup perusahaan didasarkan pada teori sinyal, karena teori sinyal membahas bagaimana sebaiknya dan seharusnya sinyal-sinyal keberhasilan atau kegagalan harus disampaikan. Diesnawati (2010) menyatakan aliran kas pendanaan pada tahap decline berpengaruh positif terhadap harga saham. Setiawan \& Nofrisel (2019) hubungan antara persediaan dan kinerja keuangan adalah positif pada tahap pertumbuhan awal dari siklus hidup organisasi dan berubah menjadi negatif pada tahap pertumbuhan akhir. Dari uraian tersebut, maka dihipotesiskan sebagai berikut.

$\mathrm{H}_{12}$ : Informasi AKP perusahaan saat tahap decline berpengaruh positif pada harga saham.

\section{METODE PENELITIAN}

Penelitian ini merupakan penelitian pengujian hipotesis. Penelitian ini dilakukan di perusahaan sektor manufaktur yang terdaftar di Bursa Efek Indonesia (BEI) tahun 2015-2019 dengan menggunakan data sekunder yaitu laporan tahunan perusahaan. populasi penelitian adalah seluruh perusahaan sektor manufaktur yang terdaftar di Bursa Efek Indonesia. Sampel adalah sebagian dari jumlah dan karakteristik yang dimiliki oleh populasi Jumlah sampel yang digunakan adalah 545 perusahaan. Metode penentuan sampel menggunakan metode purposive sampling. Teknik Analisis data yang digunakan adalah regresi linier berganda. Adapun penentuan kriteria subyek dalam penelitian ini dilakukan dengan pertimbangan sebagai berikut yakni perusahaan sampel yang dipilih masih tercatat di BEI dan aktif diperdagangkan hingga saat ini, perusahaan sampel yang 
dipilih memiliki usia listing 5 tahun dan memiliki data tahunan yang lengkap sejak tahun 2015 sampai tahun 2019, perusahaan sampel menerbitkan laporan keuangan tahunan untuk periode 1 Januari - 31 Desember.

Berikut ini dijelaskan definisi operasional dari masing-masing variabel.

Laba dalam penelitian ini merupakan hasil bersih setelah pajak. EPS (earnings per share) diperoleh dari jumlah laba yang didapat oleh setiap lembar saham biasa selama satu periode akuntansi. EPS pada penelitian ini berdasarkan pada penelitian Diesnawati (2010).

$$
\text { EPS }=\frac{\text { Laba bersih setelah bunga bank dan pajak }}{\text { Lembar saham yang beredar }}
$$

Arus kas adalah informasi tentang kas masuk variabel keluar dalam suatu periode. Arus kas operasi adalah arus kas dari aktivitas penghasil utama pendapatan perusahaan dan aktivitas lain yang bukan merupakan aktivitas investasi dan aktivitas pendanaan. Arus kas operasi diproksi dengan CFOPS (Cash Flow from Operating per Share) yang diperoleh dari arus kas operasi dibagi dengan jumlah lembar saham.

$$
\text { CFOPS }=\frac{\text { Cash Flow from Operating }}{\text { Lembar Saham }}
$$

Arus kas investasi adalah aliran kas dari pelepasan untuk perolehan aktiva jangka panjang serta investasi lain yang tidak termasuk setara kas. Aktivitas yang tertolong investasi adalah aktivitas yang terjadi secara teratur dan menyebabkan penerimaan dan pembayaran kas. Arus kas investasi diproksi dengan CFIPS (Cash Flow from Investing per Share) yang diperoleh dari arus kas investasi dibagi dengan jumlah lembar saham.

$$
\text { CFIPS }=\frac{\text { Cash Flow from Investing }}{\text { Lembar Saham }}
$$

Arus kas pendanaan adalah aliran kas dari aktivitas yang mengakibatkan perubahan jumlah serta komposisi modal dan pinjaman perusahaan. Aktivitas pendanaan mencakup transaksi dan peristiwa dimana kas itu diperoleh atau dibayarkan kepada pemilik dan kreditur misalnya penerbitan obligasi. Arus kas pendanaan diproksi dengan CFFPS (Cash Flow from Financing per Share) yang diperoleh dari arus kas pendanaan dibagi dengan jumlah lembar saham.

$$
\text { CFFPS }=\frac{\text { Cash Flow from Financing }}{\text { Lembar Saham }}
$$

Harga saham adalah nilai penyertaan atau kepemilikan seseorang dalam suatu perusahaan, Burhanuddin (2009). Harga saham dalam penelitian ini merupakan harga penutupan akhir (closing price) dalam periode pengamatan.

\section{HASIL DAN PEMBAHASAN}

Berdasarkan ketersediaan data di Bursa Efek Indonesia (BEI) diperoleh sampel sebanyak 109 perusahaan. Sampel perusahaan terbagi menjadi 3 siklus hidup perusahaan yaitu 24 perusahaan tahap growth, 62 perusahaan tahap mature dan 23 perusahaan tahap decline. Proses pengambilan sampel menggunakan 5 tahun pengamatan sehingga sampel akhir berjumlah 545 perusahaan yang terbagi dari 
120 perusahaan tahap growth, 310 perusahaan tahap mature dan 115 perusahaan tahap decline. Hasil deskriptif dari penelitian ini dijabarkan dalam Tabel 1.

Pada tahap growth, variabel laba memiliki nilai terendah $-533,687$, nilai tertinggi 9,120, mean $-8,565$ dan standar deviation 68,666 . Nilai mean laba sebesar 8,565 berarti nilai rata-rata laba perusahaan yang menjadi sampel adalah sebesar 8,565 dengan standar deviation 68,666. Standar deviation laba sebesar 68,666 menunjukkan bahwa variasi atau sebaran data variabel laba cenderung homogen, karena titik standar deviasi mendekati rata-rata, yang artinya distribusi data semakin terpusat. Variabel arus kas aktivitas operasi memiliki nilai terendah 6324,590 , nilai tertinggi 0,680 , mean $-106,962$ dan standar deviation 812,951 . Nilai mean arus kas aktivitas operasi sebesar $-106,962$ berarti nilai rata-rata arus kas aktivitas operasi perusahaan yang menjadi sampel adalah sebesar -106,962 dengan standar deviation 812,951. Standar deviation arus kas aktivitas operasi sebesar 812,951 menunjukkan bahwa variasi atau sebaran data variabel arus kas aktivitas operasi cenderung homogen, karena titik standar deviasi mendekati rata-rata, yang artinya distribusi data semakin terpusat. Variabel arus kas aktivitas investasi memiliki nilai terendah -2,347, nilai tertinggi 3091,547, mean 51,420 dan standar deviation 397,450. Nilai mean arus kas aktivitas investasi sebesar 51,420 berarti nilai rata-rata arus kas aktivitas investasi perusahaan yang menjadi sampel adalah sebesar 51,420 dengan standar deviation 397,450.

Standart deviation arus kas aktivitas investasi sebesar 397,450 menunjukkan bahwa variasi atau sebaran data variabel arus kas aktivitas investasi cenderung homogen, karena titik standar deviasi mendekati rata-rata, yang artinya distribusi data semakin terpusat. Variabel arus kas aktivitas pendanaan memiliki nilai terendah -0,193, nilai tertinggi 14044,196, mean 234,100 dan standar deviation 1805,459 . Nilai mean arus kas aktivitas pendanaan sebesar 234,100 berarti nilai rata-rata arus kas aktivitas pendanaan perusahaan yang menjadi sampel adalah sebesar 234,100 dengan standar deviation 1805,459. Standar deviation arus kas aktivitas pendanaan sebesar 1805,459 menunjukkan bahwa variasi atau sebaran data variabel arus kas aktivitas investasi cenderung homogen, karena titik standar deviasi mendekati rata-rata, yang artinya distribusi data semakin terpusat.

Pada tahap mature, variabel laba memiliki nilai terendah -0,291, nilai tertinggi 65,001, mean 3,425 dan standar deviation 12,131. Nilai mean laba sebesar 3,425 berarti nilai rata-rata laba perusahaan yang menjadi sampel adalah sebesar 3,425 dengan standar deviation 12,131. Standar deviation laba sebesar 12,131 menunjukkan bahwa variasi atau sebaran data variabel laba cenderung homogen, karena titik standar deviasi mendekati rata-rata, yang artinya distribusi data semakin terpusat.

Variabel arus kas aktivitas operasi memiliki nilai terendah -80,186, nilai tertinggi 177,679, mean 1,907 dan standar deviation 25,954. Nilai mean arus kas aktivitas operasi sebesar 1,907 berarti nilai rata-rata arus kas aktivitas operasi perusahaan yang menjadi sampel adalah sebesar 1,907 dengan standar deviation 25,954. Standar deviation arus kas aktivitas operasi sebesar 25,954 menunjukkan bahwa variasi atau sebaran data variabel arus kas aktivitas operasi cenderung homogen, karena titik standar deviasi mendekati rata-rata, yang artinya distribusi data semakin terpusat. Variabel arus kas aktivitas investasi memiliki nilai terendah -147,498, nilai tertinggi 116,914, mean -2,741 dan standar deviation 28,241. 
Nilai mean arus kas aktivitas investasi sebesar $-2,741$ berarti nilai rata-rata arus kas aktivitas investasi perusahaan yang menjadi sampel adalah sebesar -2,741 dengan standar deviation 28,241. Standar deviation arus kas aktivitas investasi sebesar 28,241 menunjukkan bahwa variasi atau sebaran data variabel arus kas aktivitas investasi cenderung homogen, karena titik standar deviasi mendekati rata-rata, yang artinya distribusi data semakin terpusat. Variabel arus kas aktivitas pendanaan memiliki nilai terendah $-17,829$, nilai tertinggi 49,386, mean 0,352 dan standar deviation 7,101. Nilai mean arus kas aktivitas pendanaan sebesar 0,352 berarti nilai rata-rata arus kas aktivitas pendanaan perusahaan yang menjadi sampel adalah sebesar 0,352 dengan standar deviation 7,101. Standar deviation arus kas aktivitas pendanaan sebesar 7,101 menunjukkan bahwa variasi atau sebaran data variabel arus kas aktivitas investasi cenderung homogen, karena titik standar deviasi mendekati rata-rata, yang artinya distribusi data semakin terpusat.

\section{Tabel 1. Statistik Deskriptif}

\begin{tabular}{|c|c|c|c|c|c|c|}
\hline & & $\mathrm{N}$ & Minimum & Махітum & Mean & Std. deviation \\
\hline \multirow[t]{8}{*}{ Growth } & Harga Saham & 120 & 50 & 7025 & 864,58 & 1399,188 \\
\hline & Laba & 120 & $-533,687$ & 9,120 & $-8,565$ & 68,666 \\
\hline & Aktivitas Operasi & 120 & $-6324,590$ & 0,680 & $-106,962$ & 812,951 \\
\hline & Aktivitas Investasi & 120 & $-2,347$ & 3091,547 & 51,420 & 397,450 \\
\hline & $\begin{array}{l}\text { Aktivitas } \\
\text { Pendanaan }\end{array}$ & 120 & $-0,193$ & 14044,196 & 234,100 & 1805,459 \\
\hline & Valid N (listwise) & 120 & & & & \\
\hline & Harga Saham & 310 & 74 & 26000 & 3300,23 & 4937,068 \\
\hline & Laba & 310 & $-0,291$ & 65,001 & 3,425 & 12,131 \\
\hline \multirow[t]{4}{*}{ Mature } & Aktivitas Operasi & 310 & $-80,186$ & 177,679 & 1,907 & 25,954 \\
\hline & Aktivitas Investasi & 310 & $-147,498$ & 116,914 & $-2,741$ & 28,241 \\
\hline & $\begin{array}{l}\text { Aktivitas } \\
\text { Pendanaan }\end{array}$ & 310 & $-17,829$ & 49,386 & 0,352 & 7,101 \\
\hline & Valid N (listwise) & 310 & & & & \\
\hline \multirow[t]{6}{*}{ Decline } & Harga Saham & 115 & 15,00 & 3595,00 & 566,91 & 865,041 \\
\hline & Laba & 115 & $-146,38$ & 1,94 & $-14,636$ & 35,305 \\
\hline & Aktivitas Operasi & 115 & $-289,20$ & 111,35 & $-20,404$ & 89,468 \\
\hline & Aktivitas Investasi & 115 & $-41,80$ & 675,11 & 38,672 & 139,864 \\
\hline & $\begin{array}{l}\text { Aktivitas } \\
\text { Pendanaan }\end{array}$ & 115 & $-0,07$ & 566,10 & 39,451 & 119,949 \\
\hline & Valid N (listwise) & 115 & & & & \\
\hline
\end{tabular}

Sumber: Data Penelitian, 2021

Pada tahap decline, variabel laba memiliki nilai terendah $-146,38$, nilai tertinggi 1,94, mean -14,636 dan standar deviation 35,305. Nilai mean laba sebesar 14,636 berarti nilai rata-rata laba perusahaan yang menjadi sampel adalah sebesar $-14,636$ dengan standar deviation 35,305. Standar deviation laba sebesar 35,305 menunjukkan bahwa variasi atau sebaran data variabel laba cenderung homogen, karena titik standar deviasi mendekati rata-rata, yang artinya distribusi data semakin terpusat. Variabel arus kas aktivitas operasi memiliki nilai terendah 289,20 , nilai tertinggi 111,35, mean -20,404 dan standar deviation 89,468. Nilai mean arus kas aktivitas operasi sebesar $-20,404$ berarti nilai rata-rata arus kas aktivitas operasi perusahaan yang menjadi sampel adalah sebesar -20,404 dengan standar 
deviation 89,468. Standar deviation arus kas aktivitas operasi sebesar 89,468 menunjukkan bahwa variasi atau sebaran data variabel arus kas aktivitas operasi cenderung homogen, karena titik standar deviasi mendekati rata-rata, yang artinya distribusi data semakin terpusat. Variabel arus kas aktivitas investasi memiliki nilai terendah $-41,80$, nilai tertinggi 675,11 , mean 38,672 dan standar deviation 139,864 . Nilai mean arus kas aktivitas investasi sebesar 38,672 berarti nilai rata-rata arus kas aktivitas investasi perusahaan yang menjadi sampel adalah sebesar 38,672 dengan standar deviation 139,864. Standar deviation arus kas aktivitas investasi sebesar 139,864 menunjukkan bahwa variasi atau sebaran data variabel arus kas aktivitas investasi cenderung homogen, karena titik standar deviasi mendekati rata-rata, yang artinya distribusi data semakin terpusat. Variabel arus kas aktivitas pendanaan memiliki nilai terendah $-0,07$, nilai tertinggi 566,10, mean 39,451 dan standar deviation 119,949. Nilai mean arus kas aktivitas pendanaan sebesar 39,451 berarti nilai rata-rata arus kas aktivitas pendanaan perusahaan yang menjadi sampel adalah sebesar 39,451 dengan standar deviation 119,949. Standar deviation arus kas aktivitas pendanaan sebesar 119,949 menunjukkan bahwa variasi atau sebaran data variabel arus kas aktivitas pendanaan cenderung homogen, karena titik standar deviasi mendekati rata-rata, yang artinya distribusi data semakin terpusat. Pada Tabel 2. dijelaskan hasil regresi dari penelitian ini.

Pengaruh Laba terhadap Harga Saham Dalam Kaitannya dengan Siklus Hidup Perusahaan. Tahap growth hipotesis menyatakan bahwa informasi laba perusahaan saat tahap growth berpengaruh positif pada harga saham. Berdasarkan hasil analisis menunjukan koefisien regresi $X_{1}$ sebesar 0,205 dengan tingkat signifikansi 0,008 yang lebih kecil dari taraf nyata 0,05 . Sehingga disimpulkan bahwa informasi laba perusahaan saat tahap growth berpengaruh positif pada harga saham. Berdasarkan hal tersebut maka hipotesis pertama diterima.

Hasil penelitian ini konsisten dengan penelitian Diesnawati (2010) dan Suprasto (2003). Sesuai juga dengan pernyataan Financial Accounting Standards Board No. 1 yang menyatakan bahwa sasaran utama laporan keuangan adalah informasi tentang prestasi laba yang disajikan melalui pengukuran laba dan komponennya, dan laba bemanfaat untuk membantu pengambilan keputusan investor dan kreditor. Perusahaan yang berada tahap growth mampu menghasilkan laba positif yang menunjukan keberhasilan dalam memperoleh pangsa pasar sehingga investor menilai perusahaan tersebut mempunyai prospek yang bagus di masa depan, sehingga jika investor menilai suatu perusahaan tersebut memiliki prospek yang bagus dimasa depan maka hal ini akan meningkatkan minat investor tersebut untuk membeli perusahaan yang berada di tahap growth dan mampu menghasilkan laba positif, jika peminat dari saham tersebut tinggi maka akan meningkatkan harga saham tersebut di bursa efek (Silalahi \& Sihotang, 2021). Tahap mature hipotesis menyatakan bahwa informasi laba perusahaan saat tahap mature berpengaruh positif pada harga saham. Berdasarkan hasil analisis menunjukan koefisien regresi $X_{2}$ sebesar 0,267 dengan tingkat signifikansi 0,000 yang lebih kecil dari taraf nyata 0,05 . Sehingga disimpulkan bahwa informasi laba perusahaan saat tahap mature berpengaruh positif pada harga saham. Berdasarkan hal tersebut maka hipotesis kedua diterima. 
Tabel 2. Hasil Uji Regresi

\begin{tabular}{|c|c|c|c|c|c|c|c|}
\hline & & $\begin{array}{l}\text { Expected } \\
\text { correlation }\end{array}$ & Coefficient & $\begin{array}{l}\text { Std. } \\
\text { Error }\end{array}$ & t-ratio & p-value & \\
\hline \multirow[t]{5}{*}{ Growth } & const & $?$ & 0,042 & 0,064 & 652 & 0,516 & \\
\hline & Laba & + & 0,205 & 0,076 & 2,709 & 0,008 & $\mathrm{p}<0,001$ \\
\hline & $\begin{array}{l}\text { Aktivitas } \\
\text { Operasi }\end{array}$ & + & 0,340 & 0,093 & 3,648 & 0,000 & $\mathrm{p}<0,001$ \\
\hline & $\begin{array}{l}\text { Aktivitas } \\
\text { Investasi }\end{array}$ & - & $-0,280$ & 0,081 & $-3,433$ & 0,001 & $\mathrm{p}<0,001$ \\
\hline & $\begin{array}{l}\text { Aktivitas } \\
\text { Pendanaan }\end{array}$ & + & 0,463 & 0,138 & 3,349 & 0,001 & $\mathrm{p}<0,001$ \\
\hline \multirow[t]{5}{*}{ Mature } & const & ? & 0,008 & 0,048 & 0,161 & 0,872 & \\
\hline & Laba & + & 0,267 & 0,068 & 3,916 & 0,000 & $\mathrm{p}<0,001$ \\
\hline & $\begin{array}{l}\text { Aktivitas } \\
\text { Operasi }\end{array}$ & + & 0,231 & 0,080 & 2,894 & 0,004 & $\mathrm{p}<0,001$ \\
\hline & $\begin{array}{l}\text { Aktivitas } \\
\text { Investasi }\end{array}$ & - & $-0,296$ & 0,088 & $-3,363$ & 0,001 & $\mathrm{p}<0,001$ \\
\hline & $\begin{array}{l}\text { Aktivitas } \\
\text { Pendanaan }\end{array}$ & + & 0,185 & 0,075 & 2,471 & 0,014 & $\mathrm{p}<0,005$ \\
\hline \multirow[t]{5}{*}{ Decline } & const & ? & 0,009 & 0,053 & 0,164 & 0,870 & \\
\hline & Laba & - & $-0,394$ & 0,090 & $-4,394$ & 0,000 & $\mathrm{p}<0,001$ \\
\hline & $\begin{array}{l}\text { Aktivitas } \\
\text { Operasi }\end{array}$ & + & 0,806 & 0,077 & 10,527 & 0,000 & $\mathrm{p}<0,001$ \\
\hline & $\begin{array}{l}\text { Aktivitas } \\
\text { Investasi }\end{array}$ & + & 0,715 & 0,350 & 2,042 & 0,044 & $p<0,005$ \\
\hline & $\begin{array}{l}\text { Aktivitas } \\
\text { Pendanaan }\end{array}$ & + & 1,129 & 0,354 & 3,186 & 0,002 & $\mathrm{p}<0,001$ \\
\hline R square & & & 0,319 & & & & \\
\hline Adj. R square & & & 0,289 & & & & \\
\hline F hitung & & & 316,611 & & & & \\
\hline Sig F hitung & & & 0,000 & & & & \\
\hline
\end{tabular}

Sumber: Data Penelitian, 2021

Hasil penelitian ini konsisten dengan penelitia Diesnawati (2010) dan Susanto \& Ekawati (2006). Perusahaan pada tahap ini sudah mapan dan mampu membiaya pertumbuhan penjualannya. Oleh karena itu, investor memperhatikan laba untuk menilai prosepek perusahaan pada tahap mature dimasa depan (Khlifi, 2021) dan (Kurniati, 2019). Tahap decline hipotesis menyatakan bahwa informasi laba perusahaan saat tahap mature berpengaruh negatif pada harga saham. Berdasarkan hasil analisis menunjukan koefisien regresi $X_{3}$ sebesar $-0,394$ dengan tingkat signifikansi 0,000 yang lebih kecil dari taraf nyata 0,05. Sehingga disimpulkan bahwa informasi laba perusahaan saat tahap decline berpengaruh negatif pada harga saham. Berdasarkan hal tersebut maka hipotesis ketiga diterima. Hasil penelitian ini menggunakan teori sinyal, karena teori sinyal membahas bagaimana sebaiknya dan seharusnya sinyal-sinyal keberhasilan atau kegagalan harus disampaikan. Teori ini menjelaskan mengapa perusahaan mempunyai inisiatif dan dorongan untuk memberikan informasi kepada pihak eksternal yaitu informasi laba perusahaan. Tahap decline perusahaan akan mengalami penurunan, dimana penjualan produk perusahaan akan mengalami kejenuhan, selanjutnya penurunan (Sihombing \& Sitanggang, 2018). Apabila 
perusahaan tidak melakukan tindakan apapun, tingkat penjualan akan semakin merosot, perusahaan akan mengalami kerugian. Hasil penelitian ini konsisten dengan penelitian Anthony \& Ramesh (1992) dan Diesnawati (2010). Pada tahap decline posisi kompetitif perusahaan sudah tidak menarik lagi, persaingan semakin tajam dan pangsa pasar potensialnya semakin sempit. Kondisi ini mempersulit kemampuan perusahaan dalam menghailkan laba.

Pengaruh Arus Kas dari Aktivitas Operasi (AKO) terhadap Harga Saham Dalam Kaitannya dengan Siklus Hidup Perusahaan. Tahap growth hipotesis menyatakan bahwa informasi arus kas aktivitas operasi perusahaan saat tahap growth berpengaruh positif pada harga saham. Berdasarkan hasil analisis menunjukan koefisien regresi $\mathrm{X}_{4}$ sebesar 0,340 dengan tingkat signifikansi 0,000 yang lebih kecil dari taraf nyata 0,05 . Sehingga disimpulkan bahwa informasi arus kas aktivitas operasi perusahaan saat tahap growth berpengaruh positif pada harga saham. Berdasarkan hal tersebut maka hipotesis keempat diterima. Jika dikaitkan dengan teori sinyal yang digunakan sebagai grand theory pada penelitian ini, teori sinyal dapat menjelaskan mengapa perusahaan mempunyai inisiatif dan dorongan untuk memberikan informasi kepada pihak eksternal (Kiessling et al., 2017), yakni informasi yang diberikan berkaitan dengan informasi arus kas aktivitas operasi perusahaan, dengan adanya teori sinyal ini pada tahap growth perusahaan mampu menghasilkan aliran kas positif yang menunjukan keberhasilan dalam memperoleh pangsa pasar dan dapat membiayai investasi besar yang akan dilakukan perusahaan (Hakim \& Putra, 2019). Hasil penelitian konsisten dengan penelitian Diesnawati (2010) dan Suprasto (2003). Perusahaan yang berada pada tahap growth mampu menghasilkan aliran kas dari aktivitas operasi positif dimana dapat memberikan informasi tambahan bagi para pemakai laporan keuangan dan laporan arus kas berhubungan dengan jumlah pembayaran deviden sehingga investor menilai perusahaan tersebut mempunyai prospek yang bagus dimasa depan (Kim, 2021) dan (Yu \& Webb, 2017).

Tahap mature hipotesis menyatakan bahwa informasi arus kas aktivitas operasi perusahaan saat tahap mature berpengaruh positif pada harga saham. Berdasarkan hasil analisis menunjukan koefisien regresi $X_{5}$ sebesar 0,231 dengan tingkat signifikansi 0,004 yang lebih kecil dari taraf nyata 0,05. Sehingga disimpulkan bahwa informasi arus kas aktivitas operasi perusahaan saat tahap mature berpengaruh positif pada harga saham. Berdasarkan hal tersebut maka hipotesis kelima diterima.

Jika dikaitkan dengan teori sinyal yang digunakan sebagai grand theory pada penelitian ini, teori sinyal dapat menjelaskan mengapa perusahaan mempunyai inisiatif dan dorongan untuk memberikan informasi kepada pihak eksternal, yakni informasi yang diberikan berkaitan dengan informasi arus kas aktivitas operasi perusahaan, dengan adanya teori sinyal ini pada perusahaan yang berada pada tahap mature mengalami puncak penjualan sehingga aliran kas operasi perusahaan yang dihailkan tinggi. Hasil penelitian ini konsisten dengan penelitian Diesnawati (2010) dan Susanto \& Ekawati (2006). Aliran kas operasi positif dan tinggi menunjukan bahwa perusahaan sudah mapan dan mampu membiayai pertumbuhan penjualannya (Neves et al., 2021).

Tahap decline hipotesis menyatakan bahwa informasi arus kas aktivitas operasi perusahaan saat tahap decline berpengaruh positif pada harga saham. Berdasarkan 
hasil analisis menunjukan koefisien regresi $\mathrm{X}_{6}$ sebesar 0,806 dengan tingkat signifikansi 0,000 yang lebih kecil dari taraf nyata 0,05. Sehingga disimpulkan bahwa informasi arus kas aktivitas operasi perusahaan saat tahap decline berpengaruh positif pada harga saham. Berdasarkan hal tersebut maka hipotesis keenam diterima.

Jika dikaitkan dengan teori sinyal yang digunakan sebagai grand theory pada penelitian ini, teori sinyal dapat menjelaskan mengapa perusahaan mempunyai inisiatif dan dorongan untuk memberikan informasi kepada pihak eksternal (Kiessling et al., 2017), yakni informasi yang diberikan berkaitan dengan informasi arus kas aktivitas operasi perusahaan, dengan adanya teori sinyal ini pada tahap decline. Hasil penelitian ini konsisten dengan penelitian Diesnawati (2010) dan Susanto \& Ekawati (2006). Perusahaan yang berada pada tahap decline, harga saham dipengaruhi oleh aliran kas operasi (Parhusip \& Khairunisa, 2015). Temuan ini menunjukan bahwa dalam menilai kinerja serta prospek masa depan perusahaan yang berada pada tahap decline, investor lebih menekankan pada aliran kas dari aktivitas operasi. Dalam hal ini aliran kas operasi mengandung informasi tentang kemapuan perusahaan mampu menghasilkan modal atas kegiatan operasinya sendiri, yakni membayar kepada para debitur dalam kasus likuidasi (Roma et al., 2020).

Pengaruh Arus Kas dari Aktivitas Investasi (AKI) terhadap Harga Saham Dalam Kaitannya dengan Siklus Hidup Perusahaan. Tahap growth hipotesis menyatakan bahwa informasi arus kas aktivitas investasi perusahaan saat tahap growth berpengaruh negatif pada harga saham. Berdasarkan hasil analisis menunjukan koefisien regresi $X_{7}$ sebesar $-0,280$ dengan tingkat signifikansi 0,001 yang lebih kecil dari taraf nyata 0,05 . Sehingga disimpulkan bahwa informasi arus kas investasi perusahaan saat tahap growth berpengaruh negatif pada harga saham. Berdasarkan hal tersebut maka hipotesis ketujuh diterima.

Hasil penelitian ini menggunakan teori sinyal, karena teori sinyal membahas bagaimana sebaiknya dan seharusnya sinyal-sinyal keberhasilan atau kegagalan harus disampaikan. Teori ini menjelaskan mengapa perusahaan mempunyai inisiatif dan dorongan untuk memberikan informasi kepada pihak eksternal yaitu informasi arus kas aktivitas investasi perusahaan.

Hasil penelitian ini konsisten dengan penelitian Black (1998) dan Diesnawati (2010). Perusahaan pada tahap growth yang arus kas aktivitas investasi bernilai negatif karena perusahaan masih melakukan investasi dalam mempertahankan pangsa pasar. Arus kas aktivitas investasi bernilai negative mencerminkan bahwa perusahaan masih melakukan investasi dalam mengusai infrastruktur, memiliki kesempatan tumbuh dan prospek yang baik dimasa depan sehingga harga saham diharapkan tinggi. Tahap mature hipotesis menyatakan bahwa informasi arus kas aktivitas investasi perusahaan saat tahap mature berpengaruh negatif pada harga saham. Berdasarkan hasil analisis menunjukan koefisien regresi $X_{8}$ sebesar -0,296 dengan tingkat signifikansi 0,001 yang lebih kecil dari taraf nyata 0,05. Sehingga disimpulkan bahwa informasi arus kas investasi perusahaan saat tahap mature berpengaruh negatif pada harga saham. Berdasarkan hal tersebut maka hipotesis kedelapan diterima.

Hasil penelitian ini menggunakan teori sinyal, karena teori sinyal membahas bagaimana sebaiknya dan seharusnya sinyal-sinyal keberhasilan atau 
kegagalan harus disampaikan. Teori sinyal menjelaskan mengapa perusahaan mempunyai inisiatif dan dorongan untuk memberikan informasi kepada pihak eksternal yaitu informasi arus kas aktivitas investasi perusahaan (Bestari \& Kiswanto, 2019) dan (Ross, 1977). Hasil penelitian ini konsisten dengan penelitian Atmini (2002) dan Susanto \& Ekawati (2006). Perusahaan pada tahap mature lebih memfokuskan pada ekspansi usahanya. Aliran kas investasi pada tahap mature bernilai negatif mencerminkan bahwa perusahaan masih memiliki peluang melakukan investasi dan prospek yang baik di masa depan sehingga harga saham diharapkan tinggi.

Tahap decline hipotesis menyatakan bahwa informasi arus kas aktivitas investasi perusahaan saat tahap decline berpengaruh positif pada harga saham. Berdasarkan hasil analisis menunjukan koefisien regresi $X_{9}$ sebesar 0,715 dengan tingkat signifikansi 0,044 yang lebih kecil dari taraf nyata 0,05. Sehingga disimpulkan bahwa informasi arus kas investasi perusahaan saat tahap decline berpengaruh positif pada harga saham. Berdasarkan hal tersebut maka hipotesis kesembilan diterima. Hasil penelitian ini menggunakan teori sinyal, karena teori sinyal membahas bagaimana sebaiknya dan seharusnya sinyal-sinyal keberhasilan atau kegagalan harus disampaikan. Teori ini menjelaskan mengapa perusahaan mempunyai inisiatif dan dorongan untuk memberikan informasi kepada pihak eksternal yaitu informasi arus kas aktivitas investasi perusahaan.

Hasil penelitian ini konsisten dengan penelitian Diesnawati (2010). Perusahaan pada tahap decline lebih banyak menjual aktiva, yaitu aktiva yang tidak produktif, daripada membeli aktiva sehingga arus kas investasi diharapkan bernilai positif (Syamita \& Sebrina, 2019). Dengan asumsi bahwa manajer membuat keputusan yang terbaik bagi kepentingan investor. Tindakan manajer menjual aktiva yang tidak produktif ini dipandang investor sebagai Tindakan dalam menyelamatkan kelangsungan hidup perusahaan. Pemilik saham berharap tindakan pihak manajemen tersebut akan mampu mengembalikan perusahaan ketahap growth atau mature, mampu menunda kegagalan selama beberapa tahun sehingga diharapkan harga saham cukup tinggi (Parhusip \& Khairunisa, 2015).

Pengaruh Arus Kas dari Aktivitas Pendanaan (AKP) terhadap Harga Saham Dalam Kaitannya dengan Siklus Hidup Perusahaan. Tahap growth hipotesis menyatakan bahwa informasi arus kas aktivitas pendanaan perusahaan saat tahap growth berpengaruh positif pada harga saham. Berdasarkan hasil analisis menunjukan koefisien regresi $X_{10}$ sebesar 0,463 dengan tingkat signifikansi 0,001 yang lebih kecil dari taraf nyata 0,05 . Sehingga disimpulkan bahwa informasi arus kas pendanaan perusahaan saat tahap growth berpengaruh postif pada harga saham. Berdasarkan hal tersebut maka hipotesis kesepuluh diterima. Hasil penelitian ini menggunakan teori sinyal, karena teori sinyal membahas bagaimana sebaiknya dan seharusnya sinyal-sinyal keberhasilan atau kegagalan harus disampaikan. Teori ini menjelaskan mengapa perusahaan mempunyai inisiatif dan dorongan untuk memberikan informasi kepada pihak eksternal yaitu informasi arus kas aktivitas pendanaan perusahaan.

Hasil penelitian ini konsisten dengan penelitian Diesnawati (2010) dan Susanto \& Ekawati (2006). Perusahaan pada tahap growth tingkat pembayaran deviden perusahaan masih rendah karena kas masih difokuskan untuk keperluan pendanaan (Parhusip \& Khairunisa, 2015). Arus kas aktivitas pendanaan positif 
mencerminkan perusahaan memiliki kesempatan tumbuh sehingga harga saham tinggi (Solechah et al., 2018). Tahap mature hipotesis menyatakan bahwa informasi arus kas aktivitas pendanaan perusahaan saat tahap mature berpengaruh positif pada harga saham. Berdasarkan hasil analisis menunjukan koefisien regresi X11 sebesar 0,185 dengan tingkat signifikansi 0,014 yang lebih kecil dari taraf nyata 0,05. Sehingga disimpulkan bahwa informasi arus kas pendanaan perusahaan saat tahap mature berpengaruh postif pada harga saham. Berdasarkan hal tersebut maka hipotesis kesebelas diterima.

Hasil penelitian ini menggunakan teori sinyal, karena teori sinyal membahas bagaimana sebaiknya dan seharusnya sinyal-sinyal keberhasilan atau kegagalan harus disampaikan. Teori ini menjelaskan mengapa perusahaan mempunyai inisiatif dan dorongan untuk memberikan informasi kepada pihak eksternal yaitu informasi arus kas aktivitas pendanaan perusahaan. Hasil penelitian ini konsisten dengan penelitian Diesnawati (2010) dan Susanto \& Ekawati (2006). Perusahaan pada tahap mature perusahaan berada pada posisi mapan dan mampu menghasilkan arus kas aktivitas pendanaan positif dalam jumlah besar (Matofani et al., 2021). Perusahaan membuhtuhkan dana besar untuk ekspansi perusahaan (Parhusip \& Khairunisa, 2015). Arus kas aktivitas pendanaan positif mencerminkan perusahaan memiliki kesempatan tumbuh sehingga diharapkan harga saham tinggi. Tahap decline hipotesis menyatakan bahwa informasi arus kas aktivitas pendanaan perusahaan saat tahap decline berpengaruh positif pada harga saham. Berdasarkan hasil analisis menunjukan koefisien regresi $\mathrm{X}_{12}$ sebesar 1,129 dengan tingkat signifikansi 0,002 yang lebih kecil dari taraf nyata 0,05 . Sehingga disimpulkan bahwa informasi arus kas pendanaan perusahaan saat tahap decline berpengaruh positif pada harga saham. Berdasarkan hal tersebut maka hipotesis keduabelas diterima.

Hasil penelitian ini menggunakan teori sinyal, karena teori sinyal membahas bagaimana sebaiknya dan seharusnya sinyal-sinyal keberhasilan atau kegagalan harus disampaikan. Teori ini menjelaskan mengapa perusahaan mempunyai inisiatif dan dorongan untuk memberikan informasi kepada pihak eksternal yaitu informasi arus kas aktivitas pendanaan perusahaan. Hasil penelitian ini konsisten dengan penelitian Diesnawati (2010) dan Susanto \& Ekawati (2006). Perusahaan pada tahap decline perusahaan memiliki kesempatan tumbuh yang terbatas, menghadapi persaingan yang semakin tajam, pangsa pasar potensial yang semakin sempit dan ekspansi yang semakin tidak menguntungkan. Penurunan ini tidak selalu mengarahkan perusahaan menuju kegagalan. Perusahaan dapat regenerasi dengan investasi pada lini produk baru, tindakan pihak manajemen tersebut akan mampu mengembalikan perusahaan ketahap growth atau mature, mampu menunda kegagalan selama beberapa tahun sehingga diharapkan harga saham cukup tinggi.

\section{SIMPULAN}

Berdasarkan hasil penelitian maka simpulan yang dapat diberikan adalah sebagai berikut Informasi laba perusahaan saat tahap growth, dan informasi laba perusahaan saat tahap mature berpengaruh positif pada harga saham, informasi laba perusahaan saat tahap decline berpengaruh negatif pada harga saham, informasi arus kas aktivitas operasi perusahaan saat tahap growth, mature dan 
decline berpengaruh positif pada harga saham. Informasi arus kas aktivitas investasi perusahaan saat tahap growth dan pada tahap mature berpengaruh negatif pada harga saham. Informasi arus kas aktivitas investasi perusahaan saat tahap decline berpengaruh positif pada harga saham. Informasi arus kas aktivitas pendanaan perusahaan saat tahap growth, mature dan decline berpengaruh positif pada harga saham perusahaan sektor manufaktur yang terdaftar di Bursa Efek Indonesia (BEI) dari tahun 2015-2019.

Berdasarkan hasil penelitian dan simpulan diatas, maka saran yang dapat diberikan adalah sebagai berikut. Bagi perusahaan yakni perusahaan pada tahap decline diharapkan untuk segera melakukan tindakan seperti menjual aktiva yang tidak produktif dan melakukan investasi pada lini produk baru sehingga mengembalikan perusahaan ketahap growth atau mature. Bagi peneliti, dikarenakan penelitian ini memiliki keterbatasan terkait sampel penelitian yang digunakan yakni hanya menggunakan sector manufaktur yang terdaftar pada Bursa Efek Indonesia, dan hanya pada kurun waktu tertentu, maka selanjutnya diharapkan dapat memperluas sampel penelitian yaitu menggunakan semua sektor yang terdaftar di Bursa Efek Indonesia (BEI) serta menambah kurun waktu penelitian yang dilakukan.

\section{REFERENSI}

Amir, P. Q., \& Suaryana, I. G. N. A. (2019). Reaksi Pasar Modal Terhadap Pengumuman Right Issue pada Perusahaan yang Terdaftar di Bursa Efek Indonesia. E-Jurnal Akuntansi, 28(1), 159-187. https://doi.org/10.24843/ eja.2019.v28.i01.p07

Ang, R. (2007). Buku Pintar Pasar Modal Indonesia (The Intelligent Guide To Indonesian Capital Market ). In Mediasoft Indonesia.

Anthony, J. H., \& Ramesh, K. (1992). Association between accounting performance measures and stock prices. A test of the life cycle hypothesis. Journal of Accounting and Economics, 15(2-3), 203-227. https://doi.org/10.1016/01654101(92)90018-W

Atmini, S. (2002). Asosiasi Siklus Hidup Perusahaan dengan Incramental ValueRelevance Informasi Laba dan Arus Kas. Jurnal Riset Akuntansi Indonesia, Vol. 5, No, 257-276.

Bestari, S. R. P., \& Kiswanto, K. (2019). Analisis Moderasi Mediasi Hubungan Arus Kas-Investasi, CSR, Dan Biaya Agensi. Jurnal Wahana Akuntansi, 14(1), 33-48. https://doi.org/10.21009/wahana.14.013

Black, E. L. (1998). Which is More Value Relevant: Earning or Cash Flows? A Life Cycle Examination. Journal of Financial Statements Analysis 4.

Bowen, Robert M, D. Burgstahler, Daley, L, A. (1986). Evidence on the Relationships Between Earning and Various Measures of Cash Flow. The Accounting Review, XI, No. 4, 213-225.

Burhanuddin. (2009). Pengaruh Earning per share terhadap harga saham. Jurnal Akuntansi Dan Keuangan. Fakultas Ekonomi, Universitas Muhammadiyah Palu, Sulawesi Tengah.

Darmadji, Tripto., Hendy, M. F. (2011). Pasar Modal Di Indonesia.

Diesnawati, N. W. (2010). Pengaruh Informasi Laba Dan Aliran Kas Pada Harga Saham Dalam Kaitannya Dengan Siklus Hidup Perusahaan. Universitas 
Udayana.

Hakim, L., \& Putra, T. (2019). Pengaruh Pertumbuhan Perusahaan, Saldo Laba, Dan Aliran Kas Operasi Terhadap Peringkat Obligasi Pada Perusahaan Real Estate Yang Terdaftar Di Bursa Efek Indonesia. JAS (Jurnal Akuntansi Syariah), 3(1), 37-47. https:// doi.org/10.46367/jas.v3i1.161

Harahap, F. (2017). Perancangan Sistem Informasi Keuangan Pada CV. Sinar Jaya. Seminar Nasional Informatika (SNIf), 1(1), 140-146.

Husna, Y. N., \& Haryanto, H. (2019). Pengaruh Siklus Hidup Perusahaan dan Corporate Social Responsibility terhadap Kebijakan Cash Holding dengan Diversifikasi Geografis sebagai Variabel Moderasi. Jurnal Ilmiah Akuntansi •, 4(2), 223-251.

Ismaya. Sujana. (2010). Kamus Akuntansi.

Khlifi, F. (2021). Web-based financial reporting, social media and information asymmetry: the case of Saudi Arabia. Journal of Financial Reporting and Accounting, ahead-of-p(ahead-of-print). https://doi.org/10.1108/JFRA-012021-0008

Kiessling, T., Martin, T. M., \& Yasar, B. (2017). The power of signaling: presidential leadership and rhetoric over 20 years. Leadership and Organization Development Journal, 38(5), 662-678. https://doi.org/10.1108/LODJ-03-2016-0059

Kim, R. (2021). Dividend reputation, dividend yield and stock returns in Korea. Journal of Derivatives and Quantitative Studies: 선물연구, 29(1), 73-99. https:/ / doi.org/10.1108/jdqs-09-2020-0023

Kurnia, D. (2019). Profitabilitas, Kebijakan Dividen dan Harga Saham Terhadap Nilai Perusahaan Pada Perusahaan Manufaktur. Jurnal Akuntansi: Kajian Ilmiah Akuntansi (JAK), 6(2), 182-186.

Kurniati, S. (2019). Stock returns and financial performance as mediation variables in the influence of good corporate governance on corporate value. Corporate Governance (Bingley), 19(2), 1289-1309. https:// doi.org/10.1108/CG-10-20180308

Lee, B. B., \& Choi, B. . (2002). Company Size, Auditor Type, and Earnings Management. Journal of Forensic Accounting.

Matofani, M., Taufiq, T., \& Sari, R. (2021). The Effect of Net Income, Company's value, Sales growth and Institutional Ownership on The Dividend Policy of Syariah Stocks and Common stocks listed in BEI in 2013-2015. Jurnal Ekonomi, Manajemen, Akuntansi Dan Keuangan, 2(4), 519-533. https:// doi.org/10.53697/emak.v2i4.263

Neves, M. E., Abreu Pinto, M., Assunção Fernandes, C. M. de, \& Simões Vieira, E. F. (2021). Value and growth stock returns: international evidence (JES). International Journal of Accounting and Information Management, 29(5), 698-733. https://doi.org/10.1108/IJAIM-05-2021-0097

Parhusip, M. F., \& Khairunisa. (2015). Pengaruh Relevansi Nilai Informasi Laba Dan Aliran Kas Terhadap Harga Saham Dalam Kaitannya Dengan Siklus Hidup Perusahaan Mariana Fatmasari Parhusip * Khairunisa. Jurnal Akuntansi Managemen, 4(1), 98-108.

Roma, C. M. da S., Louzada, L. C., Roma, P. M. da S., Goto, H., \& Souma, W. (2020). Earnings management, policy uncertainty and firm life cycle stages: evidence 
from publicly traded companies in the USA and Brazil. Journal of Financial Economic Policy, 13(3), 371-390. https://doi.org/10.1108/JFEP-02-2020-0031

Ross, S. A. (1977). Determination Of Financial Structure: The Incentive-Signalling Approach. Bell J Econ. https://doi.org/10.2307/3003485

Setiawan, F., \& Nofrisel, N. (2019). Perspektif Siklus Hidup Perusahaan Dalam Hubungan Antara Inventori Dan Kinerja Finansial. Jurnal Ekonomi Dan Bisnis. https:// doi.org/10.30659/ekobis.20.1.40-61

Setiawanta, Y., \& Hakim, M. A. (2019). Apakah sinyal kinerja keuangan masih terkonfirmasi? : Studi empiris lembaga keuangan di PT. BEI. Jurnal Ekonomi Dan Bisnis, 22(2), 289-312. https:/ / doi.org/10.24914/jeb.v22i2.2048

Sihombing, S., \& Sitanggang, D. (2018). Analisis Desain Produk Dan Jasa. Jurnal Riset Akuntansi \& Keuangan, 4(2), 137-156.

Silalahi, E. R. ., \& Sihotang, V. A. P. (2021). Pengaruh Struktur Modal, Pertumbuhan Perusahaan Dan Ukuran Perusahaan Terhadap Nilai Perusahaan Pada Perusahaan Barang Konsumsi Yang Terdaftar Di Bursa Efek Indonesia. Jurnal Riset Akuntansi \& Keuangan, 7(2), 153-166.

Simanjuntak, J. (2021). Analisis Kinerja Portofolio Saham Lq45 Sebelum Dan Selama Masa Pandemi Covid-19. Sekolah Tinggi Ilmu Ekonomi Indonesia Jakarta.

Solechah, S., Andini, R., \& Hartono. (2018). Pengaruh Komponen Arus Kas Dan Pertumbuhan Penjualan Terhadap Harga Saham Serta Struktur Modal Sebagai Variabel Intervening (Studi Kasus Pada Perusahaan Textile Dan Garment Yang Terdaftar Di Bursa Efek Indonesia Periode 2010-2015). Jurnal Ilmiah Mahasiswa S1 Akuntansi Universitas Pandanaran, 4(4), 1-20. http://weekly.cnbnews.com/news/article.html?no=124000

Sukardi, Kodrat David., Kurniawan, I. (2010). Manajemen Investasi.

Suprasto, B. (2003). Asosiasi antara Ukuran Performa Akuntansi dan Return Saham: Suatu Pengujian terhadap Hipotesis Siklus Kehidupan Perusahaan. Tesis Program Pascasarjana. Universitas Gadjah Mada.

Susanto, R. S., \& Ekawati, E. (2006). Relevansi Nilai Informasi Laba dan Aliran Kas terhadap Harga Saham dalam Kaitannya dengan Siklus Hidup Perusahaan. Simposium Nasional Akuntansi 9 Padang.

Syamita, W., \& Sebrina, N. (2019). Analisis Relevansi Nilai Capital Expenditure Pada Siklus Hidup Perusahaan Yang Berbeda. Jurnal Eksplorasi Akuntansi, 1(3), 865-882. https://doi.org/10.24036/jea.v1i3.115

Tosungku, L. O. A. S. (2021). Struktur Modal Dan Patronase Politik Di Indonesia [Universitas Isalm Indonesia]. https://dspace.uii.ac.id/handle/123456789/33443

Widiyanti, M. (2019). Prodi Magister Manajemen, Fakultas Ekonomi, Universitas Sriwijaya, Palembang, Indonesia. Jurnal Riset Akuntansi Dan Keuangan, 7(3).

Wolk, H. I., Dodd, J. L., \& Tearney, M. G. (2001). Accounting theory : a conceptual and institutional approach. South Western College Publishing.

Yendrawati, R., \& Pratiwi, R. S. I. (2015). Relevansi Nilai Informasi Laba Dan Arus Kas Terhadap Harga Saham. Jurnal Dinamika Manajemen, 5(2), 161-170. https://doi.org/10.15294/jdm.v5i2.3658

$\mathrm{Yu}$, S., \& Webb, G. (2017). The information content of dividend initiation announcements: The case of information technology firms. Managerial Finance, 43(7), 794-811. https:/ / doi.org/10.1108/MF-10-2015-028 